\title{
Benthic Habitat Modification through Excavation by Red Grouper, Epinephelus morio, in the Northeastern Gulf of Mexico
}

\author{
Felicia C. Coleman ${ }^{1, *}$, Christopher C. Koenig ${ }^{1}$, Kathryn M. Scanlon ${ }^{2}$, Scott Heppell ${ }^{3}$, Selina Hep- \\ pell $^{3}$ and Margaret W. Miller ${ }^{4}$ \\ ${ }^{1}$ Florida State University Coastal and Marine Laboratory, 3618 Coastal Highway, St. Teresa, FL 32358-2702 \\ ${ }^{2}$ U.S. Geological Survey, 384 Woods Hole Rd., Woods Hole, MA 02543-1598 \\ ${ }^{3}$ Department of Fisheries and Wildlife, 104 Nash Hall, Oregon State University, Corvallis, OR 97331 \\ ${ }^{4}$ National Marine Fisheries Service, Southeast Fisheries Science Center, 75 Virginia Beach Dr., Miami, FL 33149
}

\begin{abstract}
Red grouper (Epinephelus morio) is an economically important species in the reef fish community of the southeastern United States, and especially the Gulf of Mexico. It is relatively common in karst regions of the Gulf and is associated with low-relief rocky features devoid of overlying sediments. Working both inshore in Florida Bay, Florida (U.S.A.), and offshore in the Gulf of Mexico shelf-edge fishery reserves, Madison Swanson and Steamboat Lumps, we characterized red-grouper habitat and the associated faunal assemblages and demonstrated through a series of experiments that red grouper expose rocky habitat by excavating with their mouths and fanning with their fins to clear away surficial sediment, thereby providing habitat for themselves as well as other reef-dwelling organisms. They also maintain this habitat by periodically clearing away sediment and debris. Such maintenance provides a clean rocky substrate for the attachment of sessile invertebrates, thereby modifying habitat features to provide refuge for many other species of fish and motile invertebrates. We demonstrated increased biodiversity and abundance associated with habitat structured by red grouper, and we speculate here as to its fishery importance as habitat for other economically important species such as spiny lobster (Panulirus argus) and vermilion snapper (Rhomboplites aurorubens).
\end{abstract}

\section{INTRODUCTION}

Architecturally complex habitats support species-rich assemblages [1-6]. The genesis of the architecture can be by physical processes, like wind, currents, or geological events, or in some cases the activities of resident organisms [7,8]. Identifying these organisms and the effect of their habitat manipulations on diversity - as opposed to the more direct effects of predation $[9,10]$ or competition [6]-is an important and growing area of community interaction research.

Animals build structures for a variety of reasons that are largely related to competing needs for food, shelter, and procuring mates over the short term and for protecting young over the longer term. These "engineering" activities can have profound effects on local physical and biological habitat, thereby affecting other species at both local and landscape scales. This phenomenon is well known among terrestrial organisms ranging from beavers to prairie dogs [11, 12]. Beavers, for example, build dams to protect themselves and their broods from predation and weather and, in the process, alter the local hydrology and habitat heterogeneity for fishes, invertebrates, and migrating waterfowl [11] while increasing diversity of herbaceous plants over broader regions [13].

*Address correspondence to this author at the Florida State University Coastal and Marine Laboratory, 3618 Coastal Highway, St. Teresa, FL 32358-2702, USA; Tel: 850-697-4120; Fax: 850-697-3822;

E-mail: coleman@bio.fsu.edu.
Prairie dogs, similarly, construct extensive burrow systems to serve as nurseries. These sites also provide refuge to a host of other species [12], affecting the diversity and abundance of a suite of predators, other burrowers, and avian communities [14].

Fewer studies have documented architectural activities in offshore marine systems, where observation and manipulation of organisms to establish cause and effect is more difficult. That said, a number of marine fish species do manipulate habitat. The better-known architects include eelpouts (Zoarcidae), gobies (Gobiidae), and tilefish (Malacanthidae). In the study reported here, we investigated such activities in red grouper.

The red grouper (Epinephelus morio, Serranidae) is a territorial, sedentary species that exhibits ontogenetically distinct habitat preferences, including a shallow-water-associated juvenile stage [15] and an offshore-reef-associated adult stage that is strongly associated with karst topography [1619]. In particular, these fish favor limestone solution holes formed by past freshwater incursion. Normally, a solution hole acts as a sink, filling with sediments transported by bottom currents and surges until no longer visible from the surface. Where holes are exposed, they support a significantly more diverse community than the surrounding environment. Red grouper are strongly associated with exposed solution holes, to the extent that the holes are often called "grouper holes" [20,21], but grouper have never been demonstrated to maintain these holes actively. If they do, the potential is 


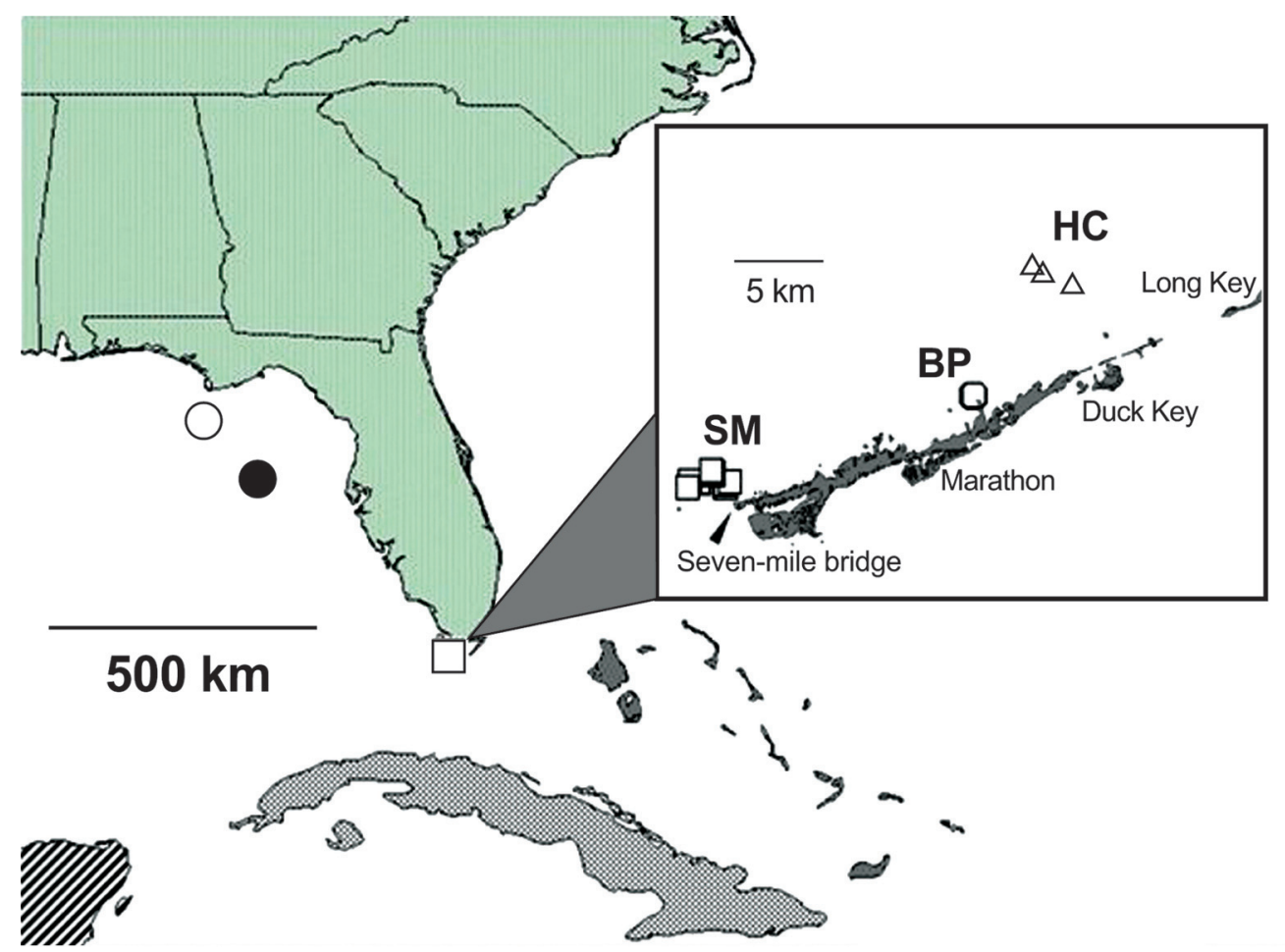

Fig. (1). Study sites in the northeastern Gulf of Mexico. Open circle, Madison Swanson Marine Reserve; black circle, Steamboat Lumps Marine Reserve; open square, Florida Keys (inset: HC, Hawks Cay; BP, Burnt Point; SM, Seven Mile Bridge).

great for community-level impacts. The objectives of our study were (1) to characterize the physical and faunal differences between red grouper holes and surrounding habitat and (2) to determine whether resident red grouper associated with these holes actively excavate and maintain the physical architecture within their habitat. Studies of the function of habitat manipulation based on findings from this study are currently under way.

\section{METHODS}

Our studies consisted of inshore and offshore components, representing, respectively, studies in juvenile and adult habitats. We evaluated juvenile habitat within Florida Bay in the Florida Keys (U.S.A.) in three areas-Hawk's Cay (HC) and Burnt Point (BP) (2000-2002) and Seven Mile Bridge (SM) (2002). We evaluated adult habitat offshore in the northeastern Gulf of Mexico within two marine reserves - the Steamboat Lumps Marine Reserve (SL) in 2000, 2001, 2004, and 2005 and the Madison Swanson Marine Reserve (MS) in 2004 (Fig. 1; Table 1). In juvenile habitat, we located grouper holes by towing scuba divers behind a boat at $1.0 \mathrm{kt}$ in parallel transects over approximately 2.0 $\mathrm{km}^{2}$ in each area. Divers temporarily marked suspected grouper holes with subsurface buoys and subsequently verified grouper presence at all sites. Using this method, we identified 24 sites each at $\mathrm{HC}$ and BP at water depths of 2 to $4 \mathrm{~m}$ and 28 grouper sites at SM at water depths of 3 to $7 \mathrm{~m}$. We chose reference areas by drifting 50-100 $\mathrm{m}$ from each site and throwing a $1-\mathrm{m}$ square quadrat from the boat. Because the direction of the current varied, this method provided a nonrandom but unbiased location for sites with which to compare habitat and diversity.
We located grouper holes offshore using a combination of fisher knowledge and side-scan sonar images; grouper presence was later verified during submarine and ROV surveys (described below). We entered all coordinates into a Global Positioning System database.

\section{Verifying Habitat Manipulation by Red Grouper}

In 2000, to determine whether juvenile red grouper could excavate solution holes in a limestone base at HC, we located sediment-filled solution holes by prodding the substrate with a 1-m fiberglass rod. Sites were chosen to have sediment depths of at least $0.3 \mathrm{~m}$ over a minimum area of 0.3 $\mathrm{m}^{2}$ (roughly the size of a grouper-inhabited solution hole). We then placed an open-bottomed cage $(1.0 \mathrm{~m}$ wide $\times 1.0 \mathrm{~m}$ long $\times 0.5 \mathrm{~m}$ high; mesh $=3 \mathrm{~cm}$ ) over each of two such sites and placed a single juvenile red grouper (38-51 cm TL) in each cage. After 48 hours, we made visual observations of sediment movement patterns and evidence of digging activity.

In 2001, we investigated habitat maintenance at $\mathrm{HC}$ and BP by introducing 4 to 5 liters of aquarium-grade charcoal particles (high-purity activated charred-bone carbon, density $>$ water; particle size 1.6-3.2 $\mathrm{mm}$ ) into 13 naturallyoccurring (= active) grouper holes ( 7 at HC, 6 at BP) at 0900 EST. Aquarium charcoal was used because it is nontoxic, easily distinguished from the naturally pale shell sand substrate surrounding the holes, and similar in particle size to existing substrate.

We checked sites for charcoal removal at 2-h intervals throughout the day. At all sites where charcoal removal occurred, we measured and recorded the maximum distance of deposition (using metric tape) and compass bearing from the 
Table 1. Overview of Field Studies Related to Use of Habitat (Specifically Solution Holes in Hard Bottom) by Red Grouper (Epinephelus morio) During their Juvenile and Adult Life Stages Along the West Florida Shelf. BP, Burnt Point, Florida Bay; HC, Hawks Cay, Florida Bay. MS, SL, sites offshore on West Florida Shelf; RG, red grouper

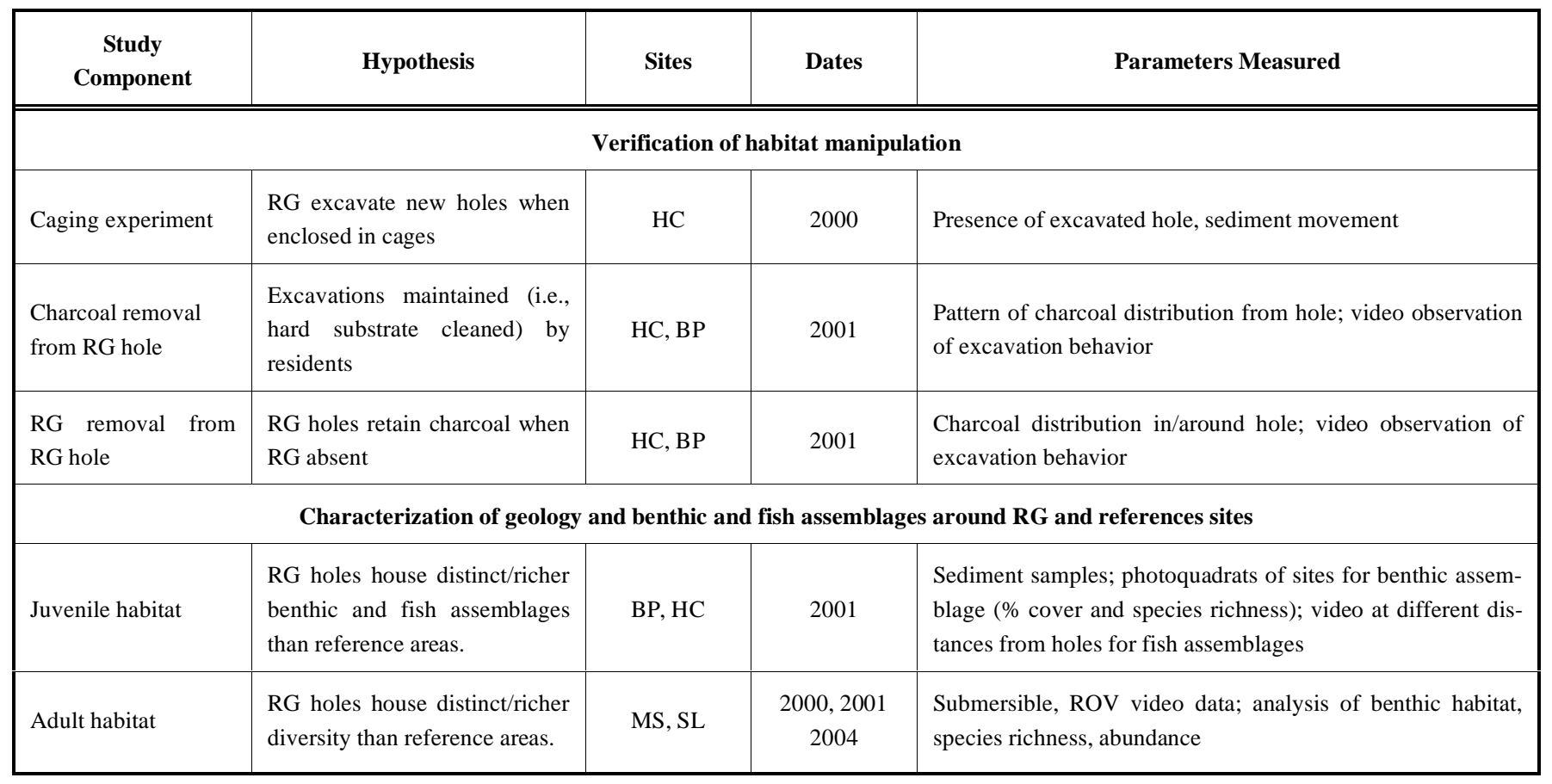

grouper hole. In addition, we placed stationary video cameras at selected sites to record species' activity.

We also performed grouper removal experiments at each location. We identified six active grouper holes in each location. We removed grouper from three holes at each location and left the remaining three holes as controls (Table 2). We introduced charcoal at all experimental and control sites immediately after grouper removal and then checked sites for charcoal removal after $24 \mathrm{~h}$. Grouper were caught with circle hooks baited with squid and were transported in a live well approximately $15 \mathrm{~km}$ from the site, where they were held separately in moored cages until termination of the experiment. Fish were then tagged with individually numbered internal anchor tags and returned to their original sites.

Table 2. Experimental Design for Removal Studies of Red Grouper, Epinephelus morio, in the Florida Keys, U.S.A. Red Grouper were Left Undisturbed $(\mathbf{R}+)$ or Removed from Sites (R-). A Reference Site (C) for Comparison of Species Diversity and Abundance was Located Approximately 100 m South of Each Site

\begin{tabular}{|c|c|c|c|c|c|c|}
\hline & \multicolumn{3}{|c|}{ Hawks Cay } & \multicolumn{3}{c|}{ Burnt Point } \\
\hline \hline No hole & CR- & CR- & CR- & CR- & CR- & CR- \\
\hline No hole & CR+ & CR+ & CR+ & CR+ & CR+ & CR+ \\
\hline Hole & R- & R- & R- & R- & R- & R- \\
\hline Hole & R+ & R+ & R+ & R+ & R+ & R+ \\
\hline
\end{tabular}

Characterization of Habitat and Fish Assemblages (Juvenile)

At active red grouper holes at $\mathrm{HC}$ and BP in 2001 and 2002, we characterized habitat within temporary square quadrats $\left(6\right.$ cell $\times 6$ cell grid; cell size $\left.=0.84 \mathrm{~m}^{2}\right)$ stabilized on sites with steel reinforcement-bar stakes. All sites were marked with underwater buoys so they could be relocated. We used unattached quadrats on grouper holes and reference sites at HC, BP, and SM in 2004. Although we did not characterize habitat at SM, it clearly differed from the $\mathrm{HC}$ and BP sites. The SM locations had strong tidal currents, in part because they were adjacent to a pass between two keys. The other two sites experienced weak currents. The HC locations were in an open area covered by sea grass and algal flats far from human-made structures, and BP locations were in areas with many rocky and coral outcrops near a seawall.

Sediment samples were collected from each site with a small shovel, and care was taken to retain fine-grained sediments. The textures of samples were classified according to the scheme of Shepard [22].

Quadrats were photographed with a digital still underwater camera (Olympus C3030 3.2 mega-pixel digital camera with a Tetra 30-30 underwater housing) for identification and quantification of biologically produced (e.g., by coral, sessile invertebrates, and algae) and geologic cover at each site. We superimposed an array of 50 randomly distributed dots on each frame, identified the substrate immediately underneath each dot, and calculated percentage cover of each substrate type. 

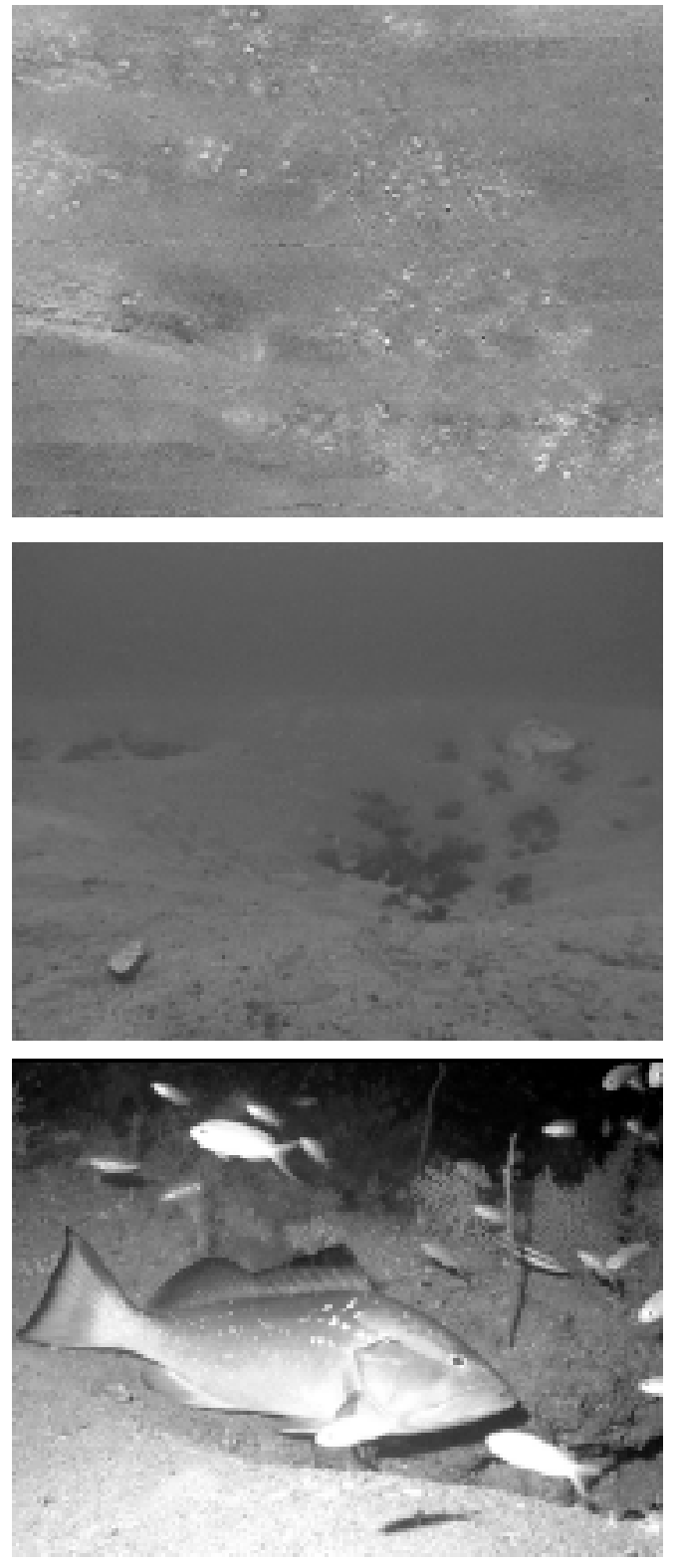

Fig. (2). Red grouper excavations in the northeastern Gulf of Mexico. Upper panel, side-scan sonar of the Steamboat Lumps Marine Reserve. Bright spots on the image are reflections from rocks at the center of each red grouper hole. Photo courtesy of the U. S. Geological Survey. Middle panel, a ground truth view of a red grouper hole with resident red grouper in attendance. Lower panel, edge of a grouper hole with red grouper in view.

We determined fish abundance, diversity, and habitat association at all sites. Divers conducted visual surveys to characterize the mobile fauna (to the lowest possible taxon) associated directly within and around all grouper holes in 2001. In 2002 we conducted stationary video-camera surveys by mounting three cameras along a randomly directed transect extending outward from the site. Camera views were perpendicular to the transect line at distances of $0 \mathrm{~m}, 3 \mathrm{~m}$, and $6 \mathrm{~m}$ from the site; the view of the $0-\mathrm{m}$ camera was directly across the solution hole. We turned on the cameras, left the site, and returned after $30 \mathrm{~min}$ to retrieve recordings. Video data included the minimum and maximum number of individuals and the activity pattern of each fish species observed at each station for each 30-min video segment. Activity patterns evaluated included milling (staying in the same spot or without directed motion for $>5 \mathrm{sec}$ ) and traversing (actively moving across the station). We analyzed the differences in fish abundance among observations using linear regression. Abundance data were log transformed to normality. Because of the small number of sampled sites, we used the jackknife method to calculate species richness at 0,3 , and $6 \mathrm{~m}$ from the grouper holes.

\section{Characterization of Habitat and Fish Assemblages (Adult)}

We characterized geomorphology in the SL and MS in 2000 using side-scan sonar images (SIS 1000), chirp seismic-reflection profiles, and sediment samples collected by Van Veen grab [20] (Fig. 2). Habitat and faunal assemblages were characterized by videography obtained by manned submersible (DeepWorker, Nuytco Research Inc., Vancouver British Columbia) in 2001 (50 h video) and by ROV (Deep Ocean Engineering Mini-Phantom) in 2004 and 2005 (20 h video) [20, 23].

For investigation of species density and abundance, each site was standardized as a circle of $4-\mathrm{m}$ radius $\left(=50 \mathrm{~m}^{2}\right)$. In SL, we evaluated 18 active, 14 inactive, and 586 sand sites. In MS, we examined 12 active, 8 inactive, and 1019 sand sites. We used the Mann Whitney test to evaluate species diversity and abundance. For each site, we counted the numbers of individuals of each sessile benthic invertebrate species and determined the maximum and minimum counts for each fish species (maximum $=$ total number seen on a given site). Although maximum counts typically overestimate the total number of individuals because of redundancy, minimum counts may be biased toward tightly schooling species. We then estimated species richness of active red grouper sites, viewing each site as a sample of a population of sites, using a jackknife method. We sampled haphazardly with the ROV and the submarine because of low visibility, variable currents, and limited time on the bottom.

\section{RESULTS}

\section{Verification of Habitat Manipulation by Red Grouper}

Each caged juvenile red grouper excavated sufficient sediment within $48 \mathrm{~h}$ to produce a subsurface excavation large enough to accommodate its entire body. Each fish actively moved sediment from solution holes to the inside perimeter of the cage (Fig. 3). In one cage, the fish escaped by digging under the cage wall.

In the excavation maintenance experiments, charcoal removal (indicative of excavation maintenance) started within $2 \mathrm{~h}$ after charcoal was deposited at the sites (Fig. 4). Most of the charcoal was removed and distributed around the site within $24 \mathrm{~h}$. Red grouper removed charcoal with their mouths and deposited it on the sediment 1-3 $\mathrm{m}$ from the excavation. The direction of deposition varied, although it often occurred in the direction of the prevailing current.

Red grouper removal experiments revealed that the juvenile red grouper at these sites were the primary, and apparently only, species maintaining excavations. (Spiny lobster, a 


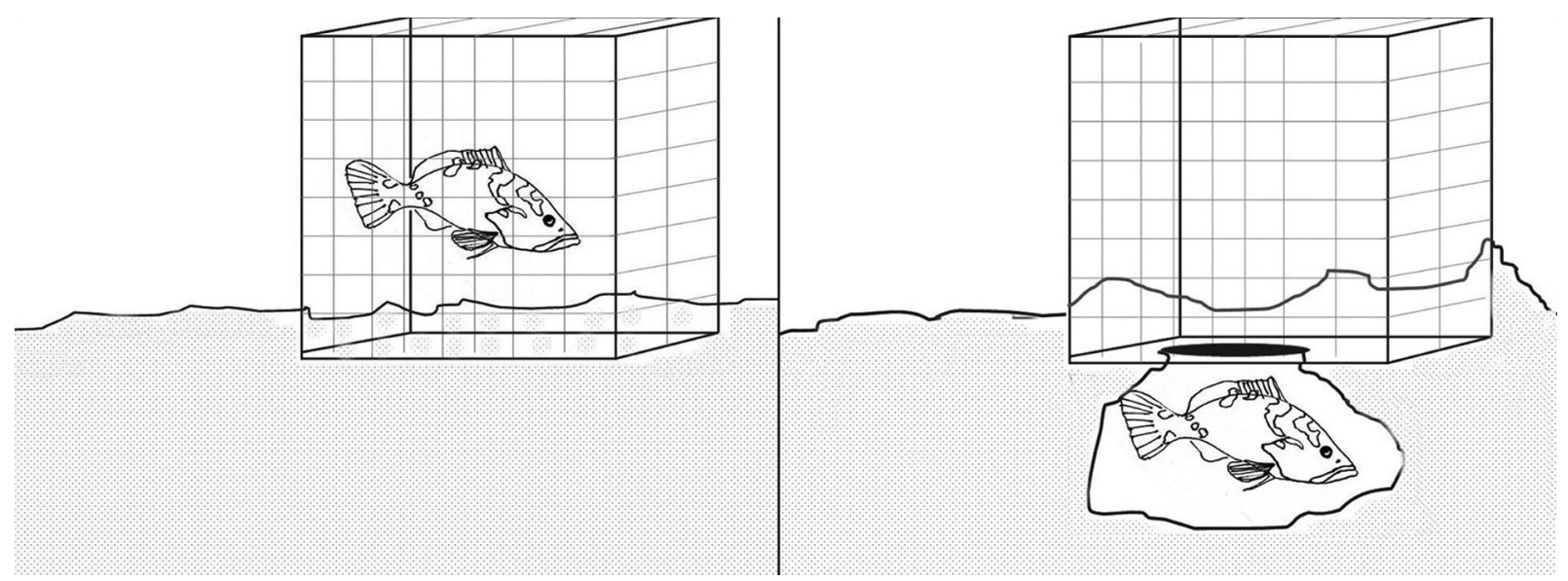

Fig. (3). Cartoon of caging experiment evaluating red grouper's ability to excavate.
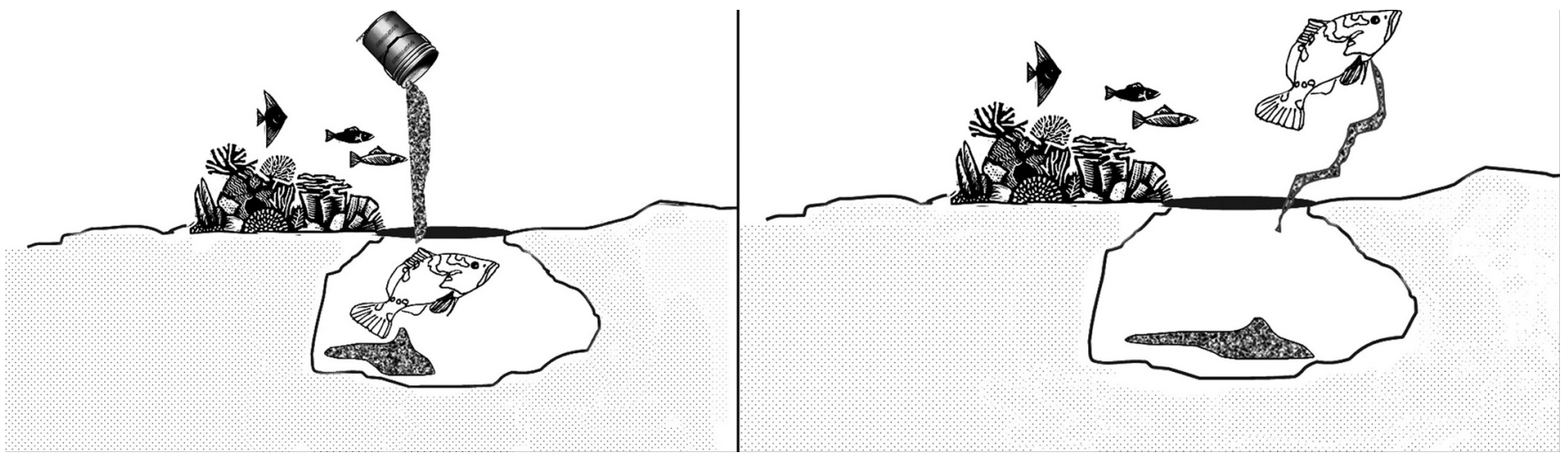

Fig. (4). Cartoon of charcoal distribution experiment in grouper hole.

common commensal in red grouper holes, pushed sediment around in only a very limited fashion.) Active distribution of charcoal occurred within 12 hours at sites harboring red grouper $(n=4)$, whereas no charcoal was distributed at sites from which grouper had been temporarily removed $(n=4)$.

\section{Characterization of Habitat and Fish Assemblages (Ju- venile)}

Geomorphology of all solution holes in juvenile habitat was similar. All sediments contained at least $85 \%$ coarse particles (sand plus gravel) and could be classed as "sand" or "sand with gravel" (in which the gravel component was $<50 \%$ or $>10 \%$ ). Particle composition was at least $95 \%$ $\mathrm{CaCO}_{3}$ primarily produced by coral, calcareous algae (Halimeda sp.), and mollusks (Table 3). Sediments produced a thin veneer over a perforated limestone base with numerous solution holes. Holes ranged in size from $\sim 1.0$ to $3.0 \mathrm{~m}^{2}$ and depths up to $1 \mathrm{~m}$.

The grouper holes and reference sites differed significantly in benthic cover (Fig. 5). At HC and BP sites, the

Table 3. Sediment Composition from Solution Holes Occupied and maintained by Red Grouper, Epinephelus morio, in the Florida Keys, Collected in 2001. BP, Burnt Point; HC, Hawks Cay; Coarse, Sand Plus Gravel; Fine, Sand Plus Clay

\begin{tabular}{|c|c|c|c|c|c|c|c|c|}
\hline Station & Sand & Gravel & Silt & Clay & Coarse & Fine & Total & Class \\
\hline \hline BP4b & 80.09 & 13.24 & 4.46 & 2.2 & 93.33 & 6.66 & 99.99 & Gravel $>10 \%$ \\
\hline BP14 & 84.34 & 8.2 & 5.39 & 2.07 & 92.54 & 7.46 & 100 & Sand \\
\hline BP16 & 74.19 & 12.02 & 9.45 & 4.34 & 86.21 & 13.79 & 700 & Gravel $>10 \%$ \\
\hline HC18 & 89.1 & 2.94 & 4.51 & 3.45 & 92.04 & 7.96 & 100 & 100 \\
\hline BP6 & 74.13 & 10.94 & 10.37 & 4.56 & 85.07 & 14.93 & Sand & Gravel $>10 \%$ \\
\hline BP6 & 86.75 & 8.69 & 2.75 & 1.82 & 95.44 & 4.57 & 100.01 & Sand \\
\hline
\end{tabular}




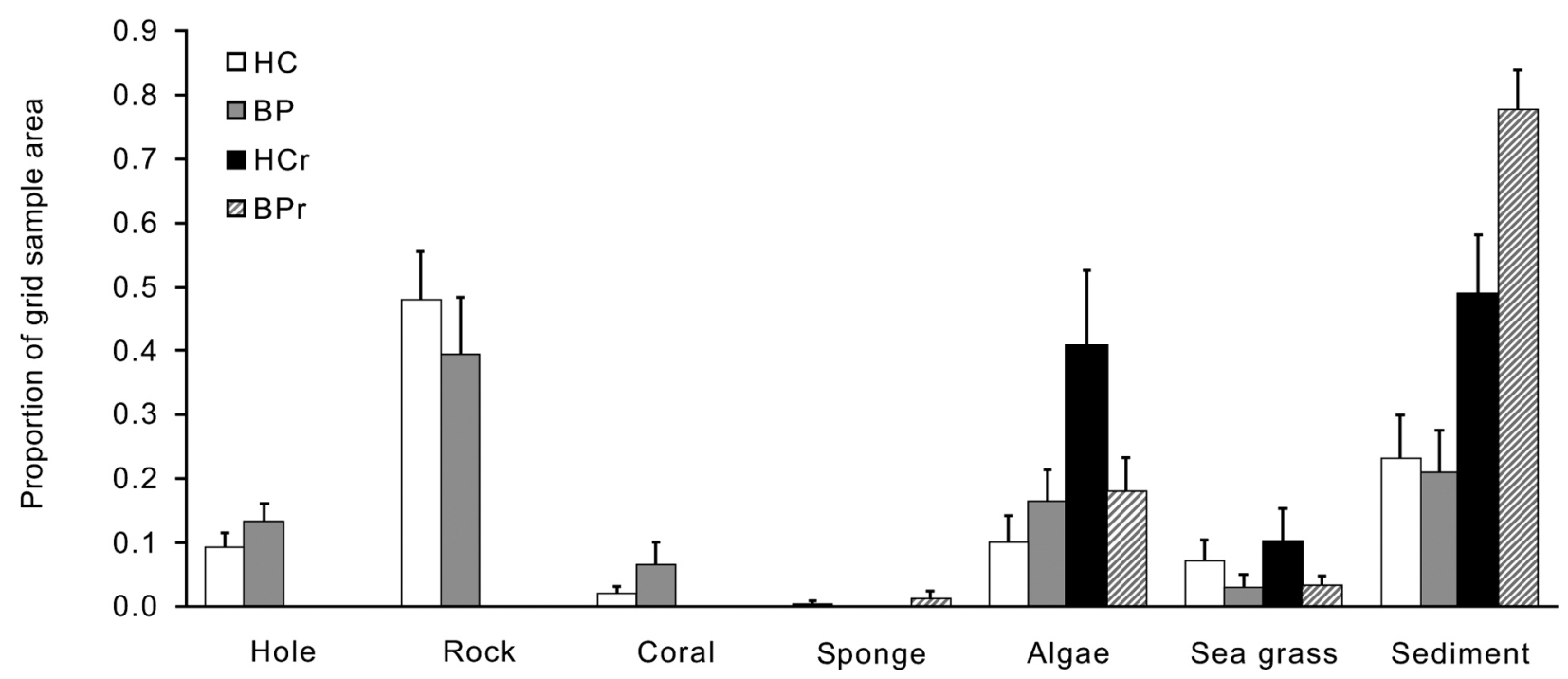

Fig. (5). Comparison of benthic cover at field sites in the Florida Keys sampled in 2001. HC, Hawk's Cay; BP, Burnt Point; r, reference site. "Hole" signifies an area actively maintained by resident grouper.

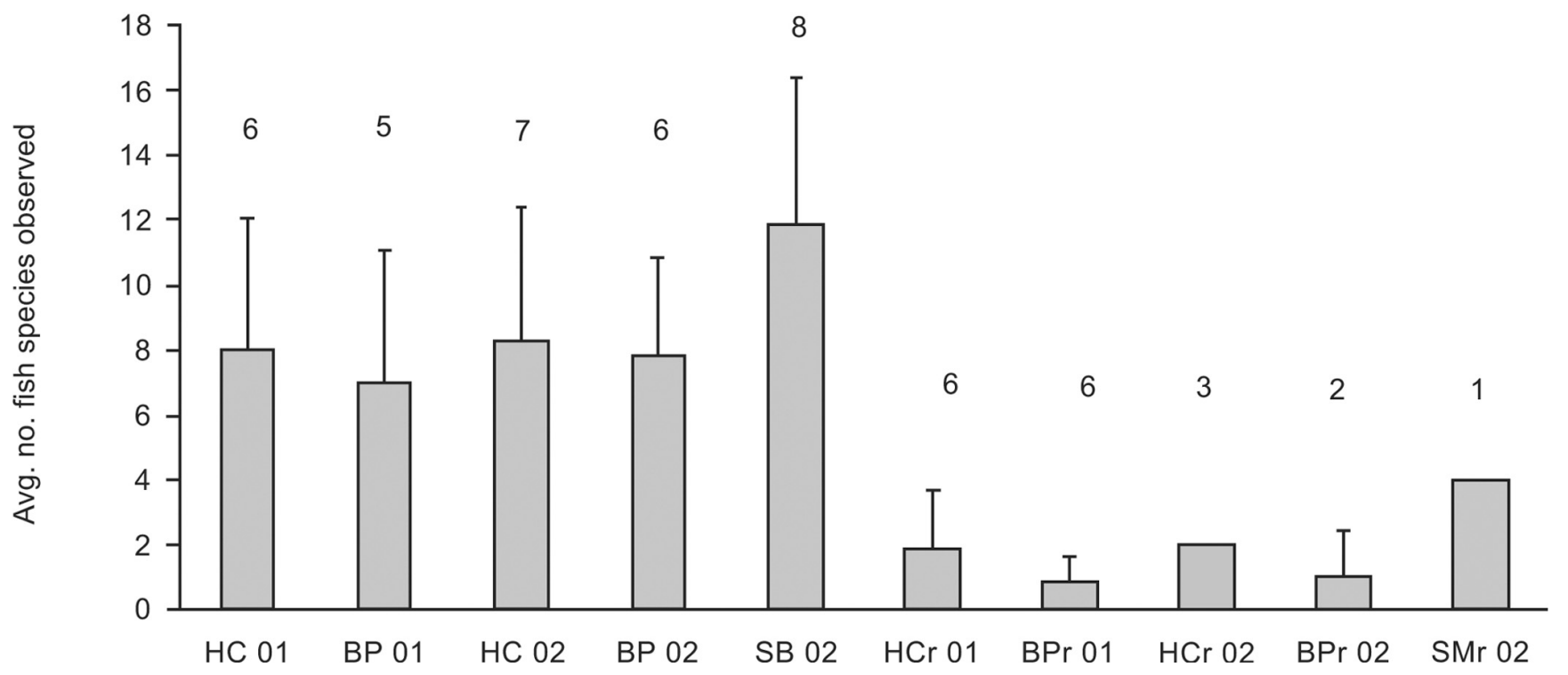

Fig. (6). Average number (and standard deviations) of fish species observed at grouper holes and references sites (r) in juvenile red grouper study areas in the Florida Keys, USA, in 2001 and 2002. Species counts were based on analysis of 30-min. video sampling by a remote camera at each site. Hawk's Cay (HC), and Burnt Point (BP) were sampled in 2001. Seven Mile Bridge (SM) was sampled in 2002 only. Numbers above bars represent number of sites.

primary substrate associated with grouper excavations was exposed rock with scleractinian corals, coralline algae, and anemones surrounded by sediment. Primary cover at reference sites was carbonate sediment, sea grass, and macroalgae.

We obtained data from $19 \mathrm{HC}$ sites ( 7 at the hole, 5 from $3 \mathrm{~m}$ away, 7 from $6 \mathrm{~m}$ away), $16 \mathrm{BP}$ sites ( 7 at the hole, 4 from $3 \mathrm{~m}$ away, 5 from $6 \mathrm{~m}$ away), and $28 \mathrm{SM}$ sites (8 at the hole, 9 from $3 \mathrm{~m}$ away, 11 from $6 \mathrm{~m}$ away). The number of fish species associated with grouper holes (Tables 4, 5) was distributed normally according to a Shapiro-Wilk test $(\mathrm{P}<$ $0.05)$. The highest number of fish species occurred directly over holes occupied by red grouper (Fig. 6; Table 5). Cleaner fish-including juvenile blue angelfish and queen angelfish - occurred at active grouper sites, whereas none was found at reference sites. The cleaner shrimp, nestled among the tentacles of the excavation-associated anemone Condolactis sp., actively cleaned red grouper. The number of fish species 
Table 4. List of Species Referred to in the Text and Tables

\begin{tabular}{|c|c|}
\hline Common Name & Scientific Name \\
\hline Almaco jack & Seriola rivoliana \\
\hline Bandtail puffer & Sphoeroides spengleri \\
\hline Bank butterflyfish & Chaetodon aya \\
\hline Bank sea bass & Centropristis ocyurus \\
\hline Blackbar drum & Equetus iwamotoi \\
\hline Black grouper & Mycteroperca bonaci \\
\hline Blue angelfish & Holacanthus bermudensis \\
\hline Blue tang & Acanthurus coeruleus \\
\hline Bluehead wrasse & Thalassoma bifasciatum \\
\hline Blue runner & Caranx crysos \\
\hline Bucktooth parrotfish & Sparisoma radians \\
\hline Cleaner shrimp & Periclimines pedersoni \\
\hline Cocoa damselfish & Stegastes variabilis \\
\hline Cottonwick & Haemulon melanurum \\
\hline Creole fish & Paranthias furcifer \\
\hline Cubbyu & Pareques umbrosus \\
\hline Damselfish & Pomacentrus sp. \\
\hline Doctorfish & Acanthurus chirurgus \\
\hline Emerald parrotfish & Nicholsina usta \\
\hline Flamefish & Apogon maculatus \\
\hline Foureye butterflyfish & Chaetodon capistratus \\
\hline French angelfish & Pomacanthus paru \\
\hline French grunt & Haemulon flavolineatum \\
\hline Garden eel & Heteroconger spp \\
\hline Goby sp. & Gobiidae \\
\hline Grass porgy & Calamus arctifrons \\
\hline Gray angelfish & Pomacantus arcuatus \\
\hline Gray snapper & Lutjanus griseus \\
\hline Gray triggerfish & Balistes capriscus \\
\hline Greenband wrasse & Halichoeres bathyphilus \\
\hline Grey triggerfish & Balistes capriscus \\
\hline Grunt & Haemulon sp. \\
\hline Highhat & Pareques acuminatus \\
\hline Hogfish & Lachnolaimus maximus \\
\hline Honeycomb cowfish & Lactophrys polygonia \\
\hline Jackknife fish & Equetus lanceolatus \\
\hline Lane snapper & Lutjanus synagris \\
\hline Lizardfish & Synodus foetens \\
\hline Ocean surgeon & Acanthurus bahianus \\
\hline Ocellate skate & Raja ackleyi \\
\hline Parrotfish & Sparisoma sp. \\
\hline Pinfish & Lagodon rhomboides \\
\hline Planehead filefish & Stephanolepis hispidus \\
\hline
\end{tabular}

\begin{tabular}{|c|c|}
\hline Common Name & Scientific Name \\
\hline Porgy & Sparidae \\
\hline Porkfish & Anisotremus viginicus \\
\hline Queen angelfish & Holacanthus ciliarus \\
\hline Red barbier & Hemanthias vivanus \\
\hline Red grouper & Epinephelus morio \\
\hline Red porgy & Pagrus pagrus \\
\hline Red snapper & Lutjanus campechanus \\
\hline Red snapper & Lutjanus campechanus \\
\hline Redband parrotfish & Sparisoma aurofrenatum \\
\hline Reticulate moray & Muraena retifera \\
\hline Roughtongue bass & Holanthias martinicensis \\
\hline Sailors choice & Haemulon parrai \\
\hline Sand perch & Diplectrum formosum \\
\hline Saucereye porgy & Calamus calamus \\
\hline Scad & Decapturus sp. \\
\hline Scalloped hammerhead & Sphryna lewini \\
\hline Scamp & Mycteroperca phenax \\
\hline Scrawled cowfish & Acanthostracion quadricornis \\
\hline Sheepshead porgy & Calamus penna \\
\hline Short bigeye & Pristigenys alta \\
\hline Slippery dick & Halichoeres bivitattus \\
\hline Spanish grunt & Haemulon macrostomum \\
\hline Speckled hind & Epinephelus drummondhayi \\
\hline Spiny lobster & Panulirus argus \\
\hline Spotfin butterflyfish & Chaetodon ocellatus \\
\hline Spotfin hogfish & Bodianus pulchellus \\
\hline Spotted goatfish & Psuedupeneus maculatus \\
\hline Squirrelfish & Holocentrus sp. \\
\hline Stingray & Dasyatis $s p$ \\
\hline Stoplight parrotfish & Sparisoma viride \\
\hline Striped burrfish & Chaetodipterus faber \\
\hline Striped parrotfish & Scarus iseri \\
\hline Tattler & Seranus phoebe \\
\hline Tobaccofish & Serranus tabacarius \\
\hline Tomtate & Haemulon aurolineatum \\
\hline Two spot cardinalfish & Apogon pseudomaculatus \\
\hline Vermilion snapper & Rhomboplites aurorubens \\
\hline White grunt & Haemulon plumieri \\
\hline Wrasse & Halichoeres sp. \\
\hline Wrasse bass & Liopropoma eukrines \\
\hline Wrasse sp. & Labridae \\
\hline Yellow stingray & Urolophus jamaicensis \\
\hline Yellowtail reeffish & Chromis enchrysura \\
\hline Yellowtail snapper & Ocyurus chrysurus \\
\hline
\end{tabular}




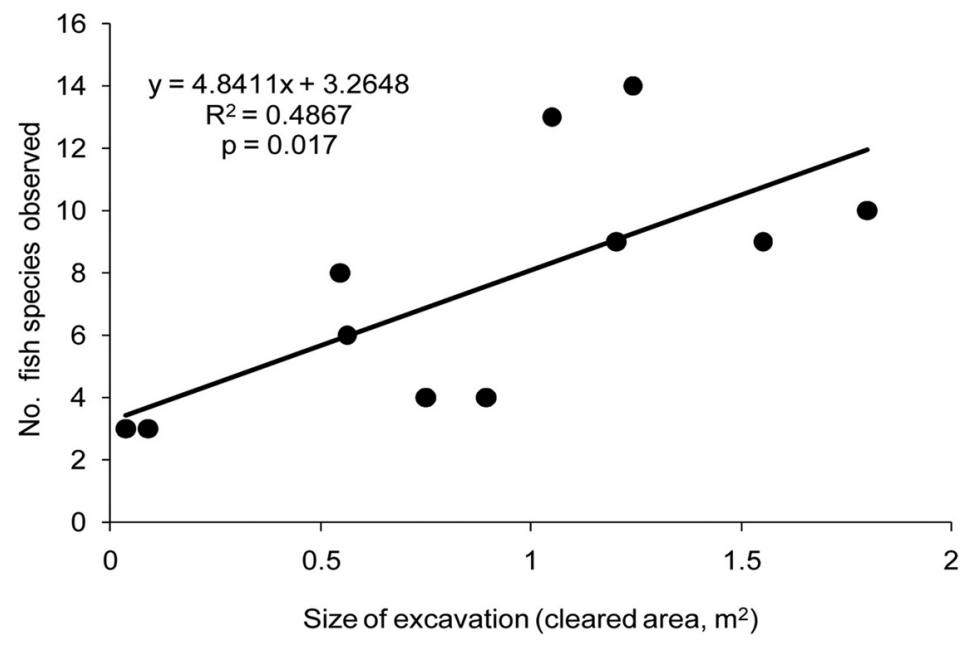

Fig. (7). Relationship between observed fish diversity and size of grouper hole for the combined Hawks Cay (HC) and Burnt Point (BP) sites in 2001. Species counts were based on analysis of 30-min. video sampling by a remote camera at each site. Area cleared of sediment at each site was estimated from diameter measurement at the site (by SCUBA divers).

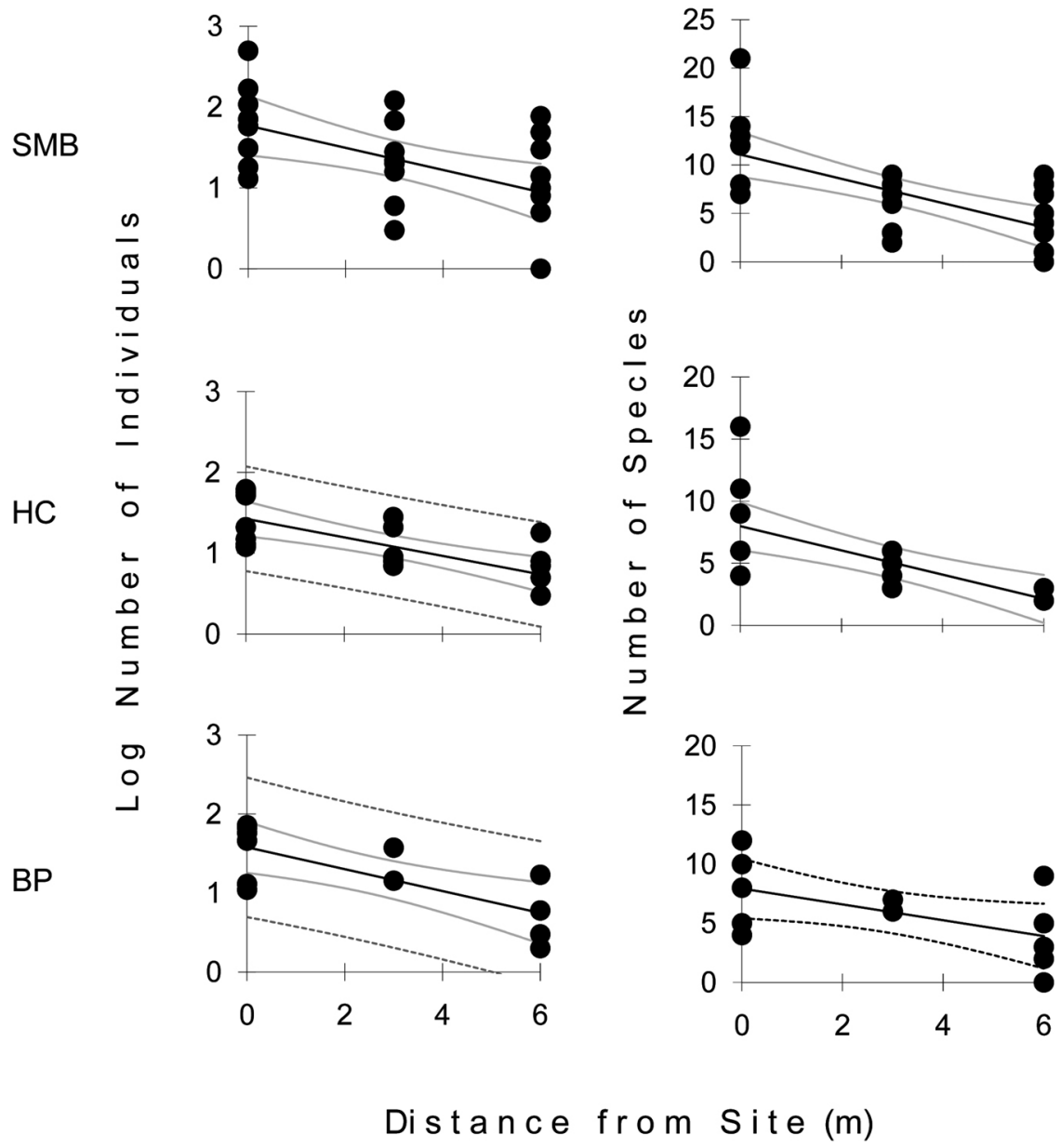

Fig. (8). Fish abundance and species diversity at three sites in the Florida Keys based on distance from red grouper Epinephelus morio holes. The average number of fish species at distant reference sites was between 1 and 4. P $<0.05$ for all graphs. Black lines, predictions; gray lines, 95\% confidence limits (CL). Fish abundance data were log transformed for normality. SM, Seven Mile Bridge; HC, Hawks Cay; BP, Burnt Point.

observed was positively correlated with the size of the excavated area (Fig. 7).

Fish abundance and diversity both declined rapidly with distance from the hole (Fig. 8). Milling behavior by fish as- sociated with grouper holes was higher directly over the hole $(=0 \mathrm{~m})$ than at distances of $3 \mathrm{~m}$ or $6 \mathrm{~m}$, generally decreasing with distance from the excavation, suggesting that fish observed at the grouper site were residents of the immediate 


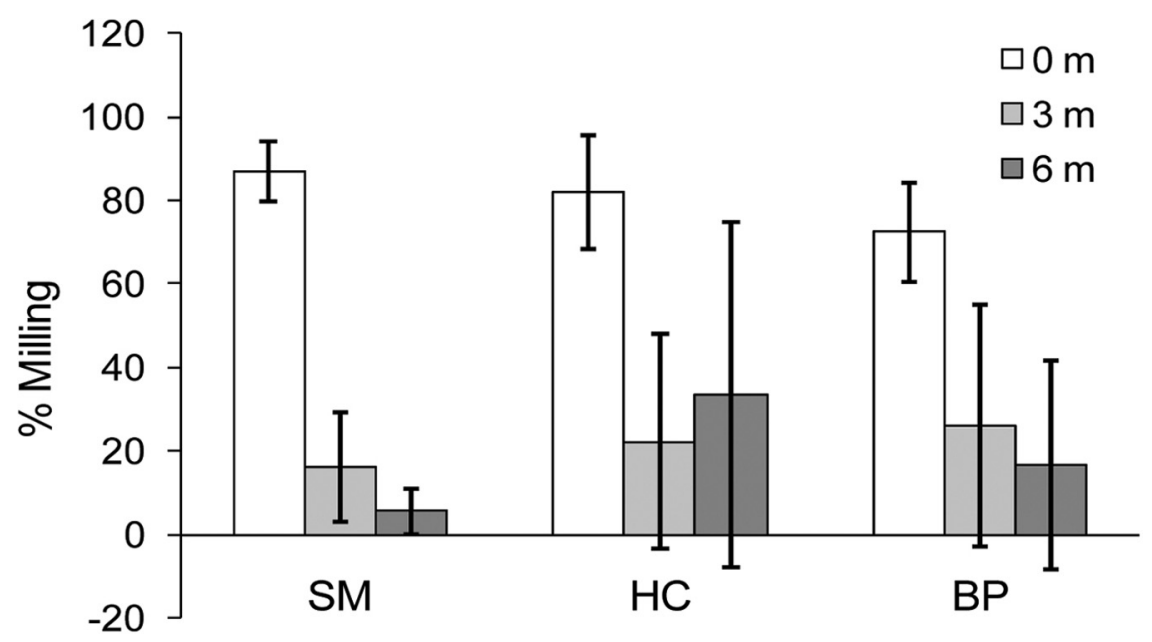

Fig. (9). Comparison of fish milling behavior at three areas in the Florida Keys, USA, as assessed by cameras located at 0,3 , and $6 \mathrm{~m}$ from grouper holes. SM, Seven Mile Bridge; HC, Hawk's Cay; BP, Burnt Point; Bars, 95 \% CL.

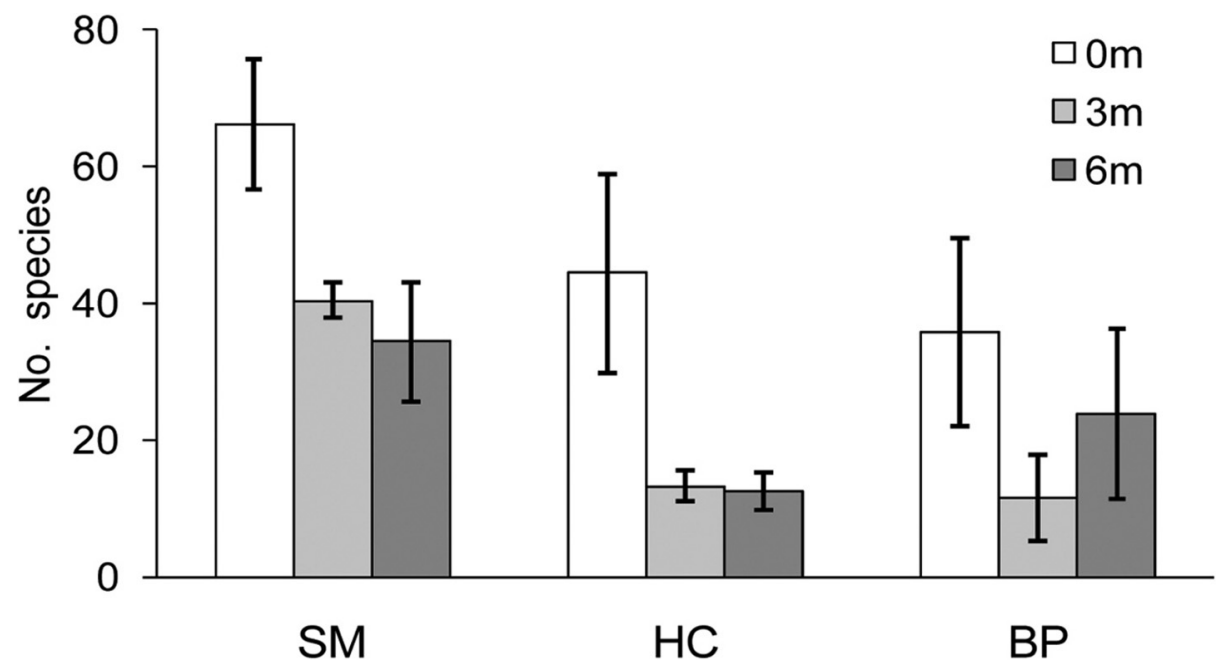

Fig. (10). Comparison of fish species richness at three areas in the Florida Keys, USA, as assessed by cameras located at 0,3 , and $6 \mathrm{~m}$ from grouper holes. SM, Seven Mile Bridge; HC, Hawk's Cay; BP, Burnt Point; Bars, 95 \% CL.

area, whereas fish observed away from the site were in transit (Fig. 9). We used a jackknife method to evaluate changes in species richness over distance $(0 \mathrm{~m}, 3 \mathrm{~m}$, and $6 \mathrm{~m})$ from red grouper holes at SM, HC, and BP. Fish species richness associated with grouper holes was highest at the $0 \mathrm{~m}$ site relative to sites $3 \mathrm{~m}$ or $6 \mathrm{~m}$ from the hole, generally decreasing with distance from the excavation (Fig. 10).

\section{Characterization of Habitat and Fish Assemblages (adult)}

The SL red grouper habitat consisted of carbonate-rock hard bottom covered with a thick (up to $10 \mathrm{~m}$ ) lens of carbonate-derived sediments. Embedded in these sediments were cone-shaped solution holes, each about 5 to $6 \mathrm{~m}$ in diameter (range $<1 \mathrm{~m}$ to $>25 \mathrm{~m}$ ) and 1-2 $\mathrm{m}$ deep. Each hole had a cluster of carbonate-rock nodules at the bottom (mean diameter $=2.5 \mathrm{~m}$; s.d. $=1.23, \mathrm{n}=3$ ) covering roughly $36 \%$ of the area. Carbonate rocks were also embedded in the sloped sides of the large holes. Large holes were often surrounded peripherally by smaller satellite holes. Holes occurred in a clumped distribution at a density of about 250 $\mathrm{km}^{-2}$ [23].
The red grouper habitat in the MS was in the northeastern area and included significant low-relief $(<1 \mathrm{~m})$ carbonaterock hard bottom in a large expanse of sand, differing from the SL in having a thin $(<1 \mathrm{~m})$ veneer of carbonate-derived sediments and in having far more relief.

Red grouper were more often present in sites that characterized by carbonate rock, either exposed at the centers of holes (SL) or on the surface (MS). We classified rock sites as active (= occupied by a resident red grouper) or inactive (= without a red grouper and filling with sediment).

Red grouper holes appeared to have distinct sessile species assemblages, depending on the availability of exposed rock substrate, although the quantification of assemblage structure was hampered by the poor resolution of sampling with remote platforms. Indeed, faunal richness for this community could not be determined because of poor lighting and the lack of a manipulator arm on the submersible for collecting samples. Most of the rock associated with SL holes was encrusted with sessile invertebrates (e.g., encrusting sponges, sea fans, corkscrew sea whips, and scattered clusters of $\mathrm{Ocu}$ lina coral) and crustose coralline algae; few benthic inverte- 


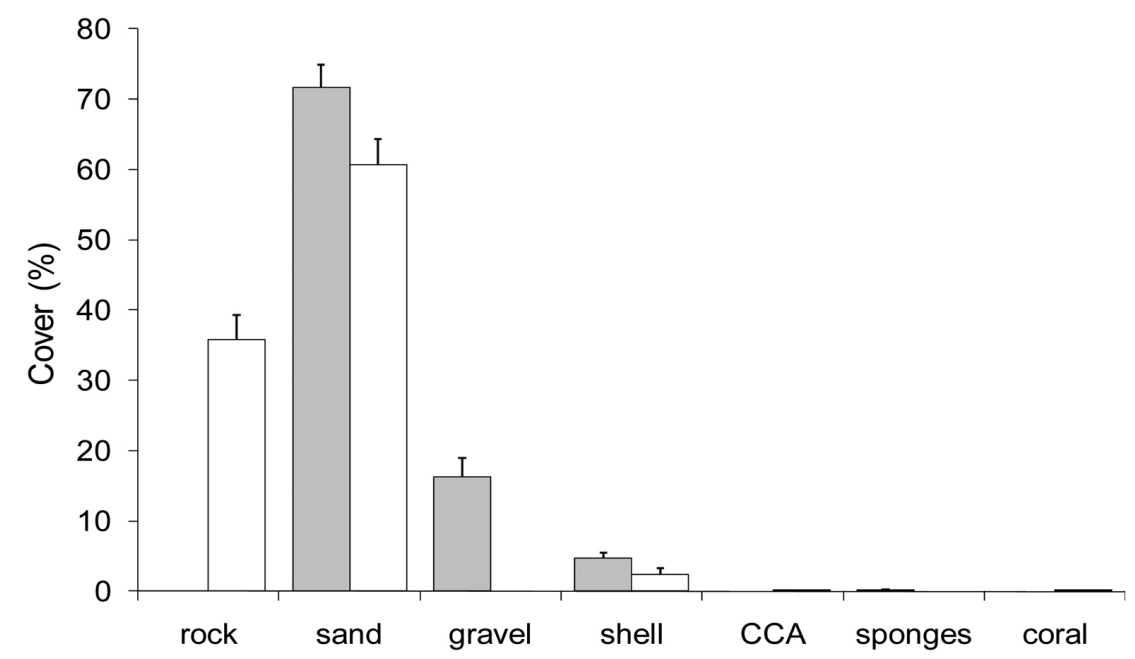

Fig. (11). Percentage cover of different substrate types in Steamboat Lumps Marine Reserve. White bars, grouper holes; grey bars, reference sites, $\mathrm{CCA}=$ crustose coralline algae.

brates occurred in the reference areas (except sponges, which were more abundant at reference sites) (Fig. 11). Certain organisms were clearly associated only with grouper sites (e.g., sea urchins), whereas others occurred only in the sandy reference areas (e.g., arborescent bryozoans and a red fleshy alga).

Table 5. Relative Species Abundances at Three Grouper-Occupied Solution Holes Within Florida Bay, in 2001 or 2002.SM, Seven Mile Bridge; HC, Hawks Cay; BP, Burnt Point

\begin{tabular}{|l|c|c|c|}
\hline \multicolumn{1}{|c|}{ Common Name } & \multicolumn{3}{c|}{ Relative Abundance } \\
\hline & SM & HC & BP \\
\hline \hline Red grouper & 5 & 6 & 3 \\
\hline White grunt & 427 & 82 & 83 \\
\hline Sailors choice & 151 & 0 & 5 \\
\hline Grunt & 105 & 23 & 85 \\
\hline Tomtate & 50 & 3 & 1 \\
\hline French grunt & 30 & 1 & 0 \\
\hline Redband parrotfish & 23 & 10 & 6 \\
\hline Lane snapper & 21 & 4 & 5 \\
\hline Gray snapper & 14 & 55 & 23 \\
\hline Yellowtail snapper & 3 & 3 & 12 \\
\hline Hogfish & 13 & 4 & 9 \\
\hline Wrasse & 12 & 1 & 0 \\
\hline Bluehead wrasse & 11 & 0 & 0 \\
\hline Doctorfish & 11 & 3 & 1 \\
\hline Spotted goatfish & 10 & 0 & 0 \\
\hline Gray angelfish & 9 & 5 & 2 \\
\hline Gray triggerfish & 6 & 2 & 0 \\
\hline Spiny lobster & 6 & 3 & 10 \\
\hline Goby & 5 & 0 & 0 \\
\hline Blue runner & 4 & 2 & 0 \\
\hline Bucktooth parrotfish & 4 & 0 & 1 \\
\hline Cottonwick & 4 & 0 & 0 \\
\hline Spanish grunt & 4 & 0 & 0 \\
\hline Black grouper & 3 & 0 & 0 \\
\hline Porkfish & 3 & 0 & 0 \\
\hline Sheepshead porgy & & & 0 \\
\hline
\end{tabular}

\begin{tabular}{|l|c|c|c|}
\hline \multirow{2}{*}{\multicolumn{1}{c|}{$\begin{array}{c}\text { Common Name } \\
\text { (cont.) }\end{array}$}} & \multicolumn{3}{c|}{ Relative Abundance } \\
\cline { 2 - 4 } & SM & HC & BP \\
\hline Stoplight parrotfish & 3 & 0 & 0 \\
\hline Blue tang & 2 & 0 & 0 \\
\hline Cocoa damselfish & 2 & 0 & 0 \\
\hline Cubbyu & 2 & 0 & 0 \\
\hline Ocean surgeon & 2 & 0 & 0 \\
\hline Slippery dick & 2 & 0 & 2 \\
\hline Flamefish & 1 & 0 & 0 \\
\hline Foureye butterflyfish & 1 & 1 & 0 \\
\hline French angelfish & 1 & 2 & 3 \\
\hline Grass porgy & 1 & 1 & 0 \\
\hline Highhat & 1 & 1 & 1 \\
\hline parrotfish & 1 & 3 & 0 \\
\hline Pinfish & 1 & 0 & 0 \\
\hline Porgy & 1 & 1 & 0 \\
\hline Queen angelfish & 1 & 0 & 0 \\
\hline Sand perch & 1 & 1 & 0 \\
\hline Striped parrotfish & 1 & 0 & 0 \\
\hline Tobaccofish & 1 & 0 & 0 \\
\hline Yellow stingray & 1 & 0 & 3 \\
\hline Bandtail puffer & 0 & 1 & 0 \\
\hline Damselfish & 0 & 1 & 1 \\
\hline Emerald parrotfish & 0 & 1 & 0 \\
\hline Honeycomb cowfish & 0 & 0 & 0 \\
\hline Planehead filefish & 0 & 0 & 0 \\
\hline Saucereye porgy & 0 & 7 & 0 \\
\hline Scalloped hammerhead & 0 & 0 & 0 \\
\hline Scrawled cowfish & 0 & 0 & 0 \\
\hline
\end{tabular}


Table 6. Species Observed at Three Types of Habitat Sites in Steamboat Lumps Marine Reserve on the West Florida Shelf during 2001 or 2004. Active Sites, Sites at which a Resident Red Grouper Occupied a Solution Hole; Inactive Sites, Solution Holes Without Resident Red Grouper; Sand, Sites Without Obvious Architecture Complexity

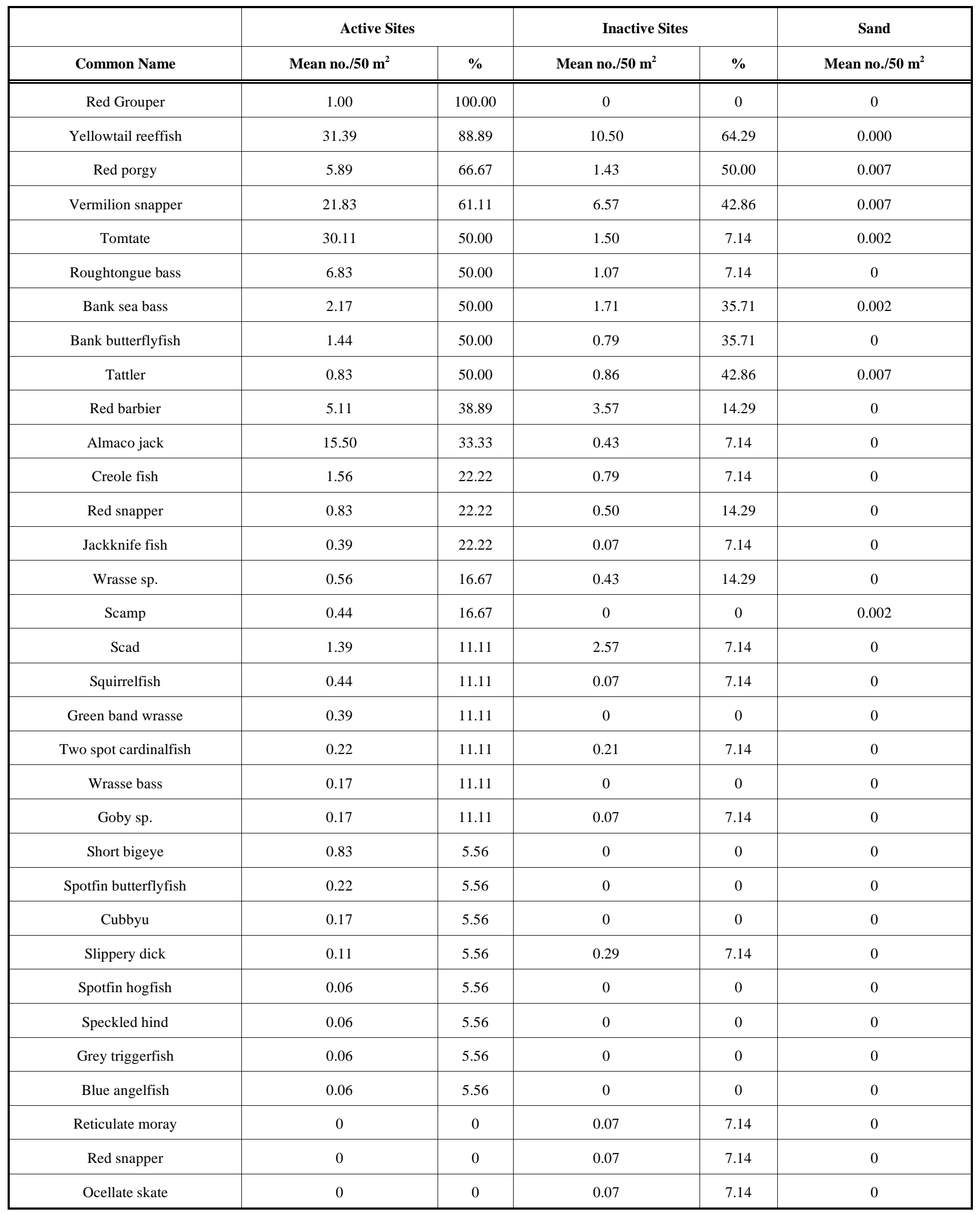


Table 7. Species List for Three Types of Habitat Sites in Madison Swanson Marine Reserve on the West Florida Shelf Compiled for 2001 and 2004. (A) Active Sites are High-Relief Reef Sites Occupied by a Resident Red Grouper; (B) Inactive Sites Are High-Relief Reef Sites Without Resident Red Grouper; (C) Sand Sites have no Obvious Architectural Structure

\begin{tabular}{|c|c|c|c|c|c|}
\hline \multirow[b]{2}{*}{ Common Name } & \multicolumn{2}{|c|}{ Active Sites } & \multicolumn{2}{|c|}{ Inactive Sites } & \multirow{2}{*}{$\begin{array}{c}\text { Sand } \\
\text { Mean no./50 } \mathrm{m}^{2}\end{array}$} \\
\hline & Mean no. $/ 50 \mathrm{~m}^{2}$ & $\%$ & Mean no. $/ 50 \mathrm{~m}^{2}$ & $\%$ & \\
\hline Roughtongue Bass & 9.67 & 66.67 & 2.25 & 37.5 & 0 \\
\hline Yellowtail reeffish & 7.83 & 58.33 & 8.75 & 50 & 0 \\
\hline Bank sea bass & 2.42 & 58.33 & 1.38 & 37.5 & 0.001 \\
\hline Bank butterflyfish & 1.33 & 58.33 & 1.25 & 50 & 0 \\
\hline Vermilion snapper & 6.33 & 50.00 & 0 & 0 & 0 \\
\hline Creole fish & 0.92 & 25.00 & 0.38 & 12.5 & 0 \\
\hline Wrasse bass & 0.42 & 16.67 & 0.13 & 12.5 & 0 \\
\hline Almaco jack & 0.33 & 16.67 & 0 & 0 & 0 \\
\hline Tattler & 0.08 & 8.33 & 0.13 & 12.5 & 0.004 \\
\hline Scad & 8.33 & 8.33 & 0 & 0 & 0 \\
\hline Jacknife fish & 0.25 & 8.33 & 0 & 0 & 0 \\
\hline Grey triggerfish & 0.08 & 8.33 & 0 & 0 & 0 \\
\hline Spotfin butterflyfish & 0 & 0 & 0.25 & 12.5 & 0 \\
\hline Lizardfish & 0 & 0 & 0 & 0 & 0.001 \\
\hline Garden eel & 0 & 0 & 0 & 0 & 0.001 \\
\hline
\end{tabular}

The SL data revealed 33 fish species (Table 6) and that for the MS 26 species (Table 7). Because 2001 and 2004 did not differ in abundance or species data (Mann Whitney P > 0.05), we pooled data for these years. Active red grouper sites overall had greater species diversity and abundance than inactive sites or sand. SL and the MS active sites differed significantly in species diversity and abundance (Mann Whitney $\mathrm{P}<0.05$ ) and species richness (Jackknife method $\mathrm{P}$ $<0.05$ ) (Fig. 12). We found no association between hole diameter in the SL and either fish density or species abundance (Pearson's correlation coefficient $\mathrm{P}>0.05$ ).

We were able to videotape red grouper performing sediment maintenance at offshore sites at 76-m depths. The fish scooped up a mouthful of sediment (including shell hash) from the center of its excavation and swam about $10 \mathrm{~m}$ away before purging the sediment from its oral and opercular cavities. The fish allowed sediment initially to trail from the opercular chamber before actively ejecting it from the oral chamber and subsequently clearing it from both opercular chambers by strong opercular contractions. After completion of oral sediment transport, the fish returned to the excavation and swept the surface with its caudal fin, suspending a large cloud of sediment over the site.

\section{DISCUSSION}

We conclude from the results we report here that red grouper act as ecological engineers, actively excavating 

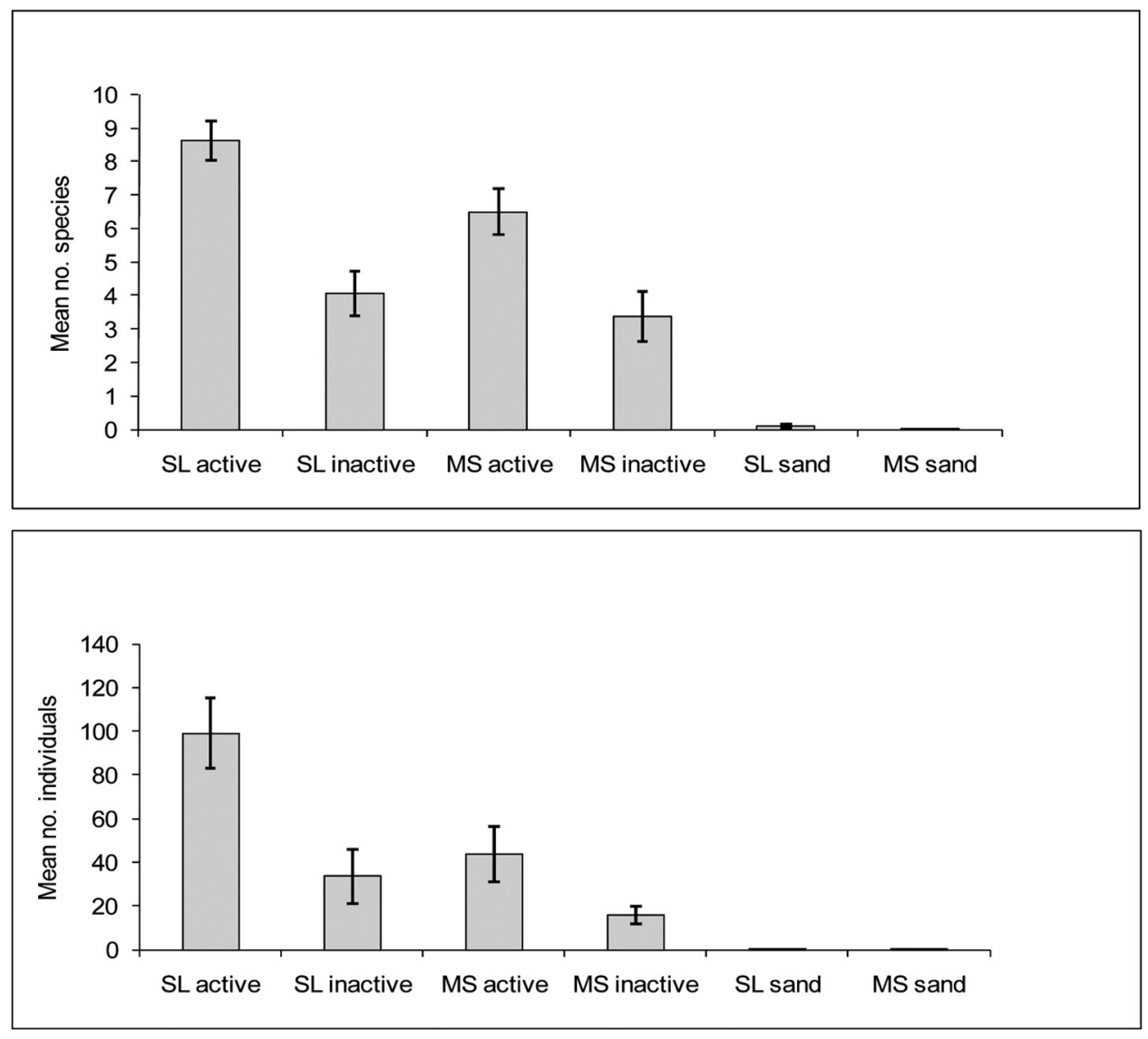

Fig. (12). Comparison of study sites on the West Florida Shelf within the Madison Swanson Marine Reserve (MS) and Steamboat Lumps Marine Reserve (SL). All sites were standardized to an area of $50 \mathrm{~m}^{2}$. Upper panel, mean number of species; lower panel, mean number of individuals. Error bars indicate standard error. "Active" signifies a site with a red grouper present. "Inactive" signifies a site with no observed grouper activity.

sediment from and maintaining sediment-free habitat around solutions holes in hard bottoms in the northeastern Gulf of Mexico. Combining these results with data from newly settled juveniles reared in captivity, which began digging immediately after settlement (C. Koenig, unpublished data), we conclude that this behavior is maintained throughout the grouper's lifetime.

Red grouper exhibit strong site fidelity, remaining in the same hole for long periods. One of the juveniles we identified in the summer of 2000 retained residence in the same grouper hole for over a year. Three individuals acoustically tagged in July 2002 were relocated after four months, two at exactly the same site and another within $100 \mathrm{~m}$ of its original site. On the shelf edge, where two of us (Koenig and Coleman) are conducting tagging studies, 14 of 15 tag returns for adult red grouper indicated no movement from original tagging sites over a one-year period.

We also found that the sites with the greatest amount of architectural structure (e.g., greater spatial extent, number of entrances, and the presence of large encrusting corals) are preferred by red grouper. When a grouper was removed from a historically stable site (as opposed to a site that appeared to have been recently excavated), a new red grouper occupied the site within $24 \mathrm{~h}$. Repeated removals were required before we could safely say that these sites were not occupied by resident red grouper. Similar results were not obtained at lower-relief sites.

Further, we suspect that these are multigenerational sites. Some actively maintained red grouper holes within Florida Bay harbored large heads ( $>0.3 \mathrm{~m}$ in diameter) of stony coral, sponges, and anemones that would suggest long-term maintenance of the site, certainly for periods longer than the residence time of the juvenile stage of an individual fish (4-5 years). Grouper holes in the deeper waters of the shelf break are so large (up to $5 \mathrm{~m}$ across and $2 \mathrm{~m}$ deep) that a substantial amount of time would be necessary for their complete excavation.

Our conclusion from both inshore and offshore studies is that active sediment removal by red grouper increases biological diversity by (1) exposing rocky substrate that provides settlement sites for sessile organisms and (2) increasing architectural complexity, which attracts many reefassociated species and provides shelter for juvenile stages of some economically important species. Red grouper holes are dramatically different from surrounding habitat and harbor a distinct community of hard-substrate-associated species, Although none of the species we observed is restricted to grouper holes, many are reef species that are not otherwise present in surrounding reference sites except as transients. 
Potential benefits for these species include protection from roving predators, increased availability of prey, and perhaps, as occurs in tilefish burrows, close proximity to cleaning stations - all of which contribute to the biodiversity of the area.

The benefits of excavation to red grouper is another question. From their behavior, we are encouraged to pursue three distinct lines of inquiry: (1) the potential health benefits of attracting cleaner species; (2) the trophic benefit of attracting food; and (3) the reproductive benefits of attracting mates. We are presently engaged in studies of grouper reproductive behavior and have observed females entering the sites of males (and not the other way around) during the spawning season.

\section{FISHERY IMPLICATIONS}

We found several economically important species associated with red grouper holes. Inshore, we found black grouper and spiny lobster of harvestable size. The association with lobster is of considerable interest because of its high frequency. Lobsters are nocturnal predators, seeking refuge during the day. In much of the shallow hard-bottom region we studied, grouper holes provide important diurnal refugia for them. Because lobster survival is strongly correlated with shelter availability [24-26], the occurrence of grouper holes could influence lobster survivorship in a region where recreational lobster fishing is intense. (Nearly 50,000 recreational lobster fishers participate in a 2-day recreational season in late July, and nearly 60,000 participate in the first month alone of a later eight-month season.) Offshore, we found that red grouper holes attracted almaco jacks, red porgy, and significant numbers of juvenile vermilion snapper. The extent to which these sites serve as nursery habitat for vermilion is unknown, but we have not seen similar densities of vermilion anywhere else.

Red grouper have been harvested in the United States since the 1880 s and are currently the most common grouper species landed in both commercial and recreational fisheries of the Gulf of Mexico. Juvenile red groupers are protected from exploitation to some extent by a size limit (currently 18 inches, $45.7 \mathrm{~cm}$, for commercial fishing, http://www.gulfcouncil.org/Beta/GMFMCWeb/downloads/c om\%20brochure\%202009-10.pdf, and 22 inches, $56 \mathrm{~cm}$, for recreational fishing, http://www.gulfcouncil.org/Beta/ GMFMCWeb/downloads/recbrochure2009-10.pdf, and 22 inches overall at the time of the study), but incidental catch and subsequent release of these fish may disrupt habitat maintenance. The extent to which juveniles are harvested during the intensive recreational lobster season is unknown, although we observed some harvest during the present study and suspect that the sheer number of people seeking lobsters in grouper holes certainly displaces them and may significantly increase movement away from their home sites.

Red grouper populations in the Gulf of Mexico and South Atlantic fishery regions of the southeastern United States have experienced intense fishing since the 1970s. They are clearly susceptible to exploitation [16]. The U. S. Atlantic coast population is overfished (http://www.nmfs.noaa.gov/ sfa/domes_fish/StatusoFisheries/2008/4thQuarter/Summary_
FSSI_Stocks.pdf), whereas the Gulf of Mexico population has alternately been considered overfished in the early 2000 s and recovered a few years later [27, 28]. Its current status is being reevaluated (http://www.sefsc.noaa.gov/sedar/SEDAR_PlanSchedule_Jan2009.pdf), on the basis of concerns that red tide has had a substantial negative effect on recruitment that has influenced the population status (ftp://ftp.gulfcouncil.org/2009\%20Gag\%20and\%20Red $\% 20$ Grouper\%20Update\%20Assessment/). An update will be forthcoming within months.

Fishery removals, particularly those that exceed sustainable levels, can and often do have cascading effects in marine communities that ultimately result in the loss of biodiversity and extreme community flux $[9,10]$. This situation arises when the captured species has a disproportionately large per capita influence on the system within which it lives. We contend that red grouper, through habitat manipulation, play an important role in increasing biodiversity and influencing community dynamics. Its loss through fishing could therefore erode local biodiversity. Indeed, the problem is perhaps exacerbated for species like red grouper and tilefish that have multiple ecological roles that may have synergistic influences on biodiversity over broad spatial scales.

Red grouper clearly remove sufficient carbonate sediment to transform an otherwise two-dimensional area into a three-dimensional structure below the seafloor, providing refuge for themselves and for other organisms. In the process, they expose hard substrate, thus creating settlement sites for corals, sponges, and anemones, allowing the creation of three-dimensional structure above the seafloor as well. Addition of these roles to their trophic contribution as resident apex predators suggests that they might have a disproportionately large per capita influence on the ecosystem within which they live. Demonstration of the interaction strengths between the engineer and the other species associated with the restructured habitat would reveal the system's level of dependence on the activities of the red grouper itself.

\section{ACKNOWLEDGEMENTS}

For offshore field support, we thank S. Earle (National Geographic Society Explorer in Residence), G. P. Schmahl, E. Hickerson, D. Weaver (Flower Gardens National Marine Sanctuary), and the crews of the R/V Oregon II, the R/V Gordon Gunter, the D/V Spree (Nuytco), and the R/V Bellows. For inshore field support, we thank the Florida Keys National Marine Sanctuary, T. Sheridan (Florida State University), P. Koenig, A. Koenig, L. Catanach, and T. Catanach. We thank two anonymous reviewers and Dr. Anne Thistle (Florida State University) for their very helpful comments on the manuscript. Financial support was provided by the Marine Conservation Biology Institute; The Pew Conservation Fellows Program; National Sea Grant (project number: R/LR-B-51); the National Undersea Research Center at the University of North Carolina, Wilmington (NOAA Grant \#03OAR4300088); and NOAA's MARFIN Program (NA17FF2876). The National Oceanic and Atmospheric Administration graciously provided use of the R/V Gordon Gunter, and we thank the Nuytco manned 
submersible and the National Geographic Society's Sustainable Seas Expedition for use of video cameras offshore. This research was conducted under permits from the Florida Keys National Marine Sanctuary (permit no. FKNMS-2005-050) and a Florida Fish and Wildlife Conservation Commission Special Activities Permit. Coleman, Koenig, Scanlon, and Miller are responsible for offshore studies. All coauthors participated in inshore studies.

\section{REFERENCES}

[1] Sale PF, Dybdahl R. Determinants in community structure for coral reef fishes in an experimental habitat. Ecology 1975; 56: 1343-45.

[2] Williams DM. In: Sale PF, Ed. The ecology of fishes on coral reefs. San Diego: Academic Press; 1991; pp. 437-74.

[3] Auster PJ, Malatesta RJ, LaRosa SC. Patterns of microhabitat utilization by mobile megafauna on the southern New England (USA) continental shelf and slope. Mar Ecol Prog Ser 1995; 127: 77-85.

[4] Auster PJ, Joy K, Valentine PC. Fish species and community distributions as proxies for seafloor habitat distributions: the Stellwagen Bank National Marine Sanctuary example (Northwest Atlantic, Gulf of Maine). Environ Biol Fish 2001; 60: 331-46.

[5] Diaz RJ, Cutter GR, Able KW. The importance of physical and biogenic structure to juvenile fishes on the shallow inner continental shelf. Estuaries 2003; 26: 12-20.

[6] Fishelson L. Coral and fish biocoenosis: ecological cells gradually maturing in complexity, species composition and energy turnover. Environ Biol Fish 2003; 68: 391-405.

[7] Jones CG, Lawton JH, Shachak M. Organisms as ecosystem engineers. Oikos 1994; 69: 373-86.

[8] Jones CG, Lawton JH, Shachak M. Positive and negative effects of organisms as physical ecosystem engineers. Ecology 1997; 78: 1946-57.

[9] Pauly D, Christensen V, Dalsgaard J, Froese R, Torres F. Fishing down the marine food webs. Science 1998; 279: 860-3

[10] Steneck RS. Human influences on coastal ecosystems: does overfishing create trophic cascades? Trends Ecol Evol 1998; 13: 42930.

[11] Gould JL, Gould CG. Animal architects: building and the evolution of intelligence. New York: Basic Books 2007.

[12] Hoogland JF. The black tailed prairie dog: social life of a burrowing animal. Chicago, Illinois: University of Chicago Press 1995.

[13] Wright JP, Jones CG, Flecker AS. An ecosystem engineer, the beaver, increases species richness at the landscape scale. Oecologia 2002; 132: 96-101.
[14] Smith GA, Lomolino MV. Black-tailed prairie dogs and the structure of avian communities on the shortgrass plains. Oecologia 2003; 138: 592-602.

[15] Moe MAJ. Biology of the red grouper (Epinephelus morio Valenciennes) from the eastern Gulf of Mexico. Professional Papers Series 10, Florida Marine Laboratory, St. Petersburg, FL. 1969; 95 p. 95.

[16] Coleman FC, Koenig CC, Collins LA. Reproductive styles of shallow-water grouper (Pisces: Serranidae) in the eastern Gulf of Mexico and the consequences of fishing spawning aggregations. Environ Biol Fish 1996; 47: 129-41.

[17] Koenig C, Coleman FC, Eklund AM, Schull J, Ueland JS. Mangroves as essential nursery habitat for goliath grouper (Epinephelus itajara). Bull Mar Sci 2007; 80: 567-86.

[18] Wilson RR, Burns KM. Potential survival of released groupers caught deeper than $40 \mathrm{~m}$ based on shipboard and in-situ observations, and tag-recapture data. Bull Mar Sci 1996; 58: 234-47.

[19]. Schirripa MJ, Legault CM, Ortiz M. The red grouper fishery of the Gulf of Mexico: Assessment 3.0. Stock assessment SFD 98-99-56, Sustainable Fisheries Division, Southeast Fisheries Science Center, Miami, Florida. 1999; p. 58.

[20] Scanlon KM, Koenig CC, Coleman FC, Miller M. Importance of geology to fisheries management: examples from the northeastern Gulf of Mexico. Am Fish Soc Symp 2003; 36: 95-9.

[21] Coleman FC, Williams SL. Overexploiting marine ecosystem engineers: potential consequences for biodiversity. Trends Ecol Evol 2002; 17: 40-4.

[22] Shepard FP. Nomenclature based on sand-silt-clay ratios. J Sediment Petrol 1954; 24: 151-8.

[23] Scanlon KM, Coleman FC, Koenig CC. In: Barnes PW, Thomas JP, Eds. Benthic habitats and the effects of fishing. Bethesda, Maryland. Am Fish Soc 2005; 301-12.

[24] Herrnkind WF, Butler MJ. Factors regulating postlarval settlement and juvenile microhabitat use by spiny lobster Panulirus argus. Mar Ecol Prog Ser 1986; 34: 23-30.

[25] Eggleston DB, Lipcius RN, Miller DL, Cobacetina L. Shelter scaling regulates survival of juvenile Caribbean spiny lobster Panulirus argus. Mar Ecol Prog Ser 1990; 62: 79-88.

[26] Smith KN, Herrnkind WF. Predation on early juvenile spiny lobsters Panulirus argus (Latreille)—influence of size and shelter. J Exp Mar Biol Ecol 1992; 157: 3-18.

[27] SEDAR (Southeast Data Assessment and Review). Stock Assessment Report Gulf of Mexico Red Grouper SEDAR 12. Southeast Fisheries Science Center, Charleston, South Carolina 2006.

[28] Cass-Calay SL, Brown CA. Stock assessment of red grouper (Epinephelus morio) in the U.S. Gulf of Mexico. Sustainable Fisheries Division Contribution No. SFD-2007-003, NOAA Fisheries, Southeast Fisheries Science Center, Miami, Florida 2007; p. 63. 